\title{
PENERAPAN PEMBELAJARAN KONTEKSTUAL DALAM \\ MENINGKATKAN HASIL BELAJAR SISWA PADA \\ MATA PELAJARAN IPA DI KELAS VI \\ SD NEGERI 101801 KEDAI DURIAN
}

\section{Paridah}

Surel: paridah@gmail.com

\begin{abstract}
ABSTRAK
Tujuan penelitian ini adalah untuk untuk meningkatkan hasil belajar siswa dengan menerapkan pembelajaran kontekstual pada mata pelajaran IPA pokok bahasan energi dan perubahannya di Kelas VI SD Negeri 101801 Kedai Durian.Bentuk penelitian ini adalah Classroom Action Research (Penelitian Tindakan Kelas). Tindakan yang dilakukan terdiri dari dua tindakan dalam dua siklus. Tiap siklus terdiri dari empat tahapan yaitu planning, acting, observing, dan reflecting.Dapat disimpulkan bahwa dengan menerapkan pembelajaran kontekstual dapat meningkatkan hasil belajar siswa pada mata pelajaran IPA pokok bahasan energi dan perubahannya di Kelas VI SD Negeri 101801 Kedai Durian tahun ajaran 2015-2016.
\end{abstract}

Kata Kunci : Pembelajaran Kontekstual, Hasil Belajar, Siswa

\section{PENDAHULUAN}

Pada dasarnya pendidikan merupakan proses yang membantu manusia dalam mengembangkan potensi yang ada pada dirinya agar mampu menghadapi perubahanperubahan yang terjadi. Melalui pendidikan, manusia dapat meningkatkan pengetahuan, kemampuan dan kreativitas terhadap perkembangan ilmu pengetahuan dan teknologi (IPTEK).

Di tingkat sekolah dasar, mata pelajaran IPA merupakan mata pelajaran yang penting diajarkan. Hal ini dikarenakan Ilmu Pengetahuan Alam (IPA) menawarkan cara-cara untuk kita sebagai penghuni alam semesta ini agar dapat memahami fenomena-fenomena yang terjadi di alam. IPA juga merupakan kumpulan pengetahuan atau kumpulan faktafakta serta peristiwa-peristiwa yang berkaitan dengan alam. Dengan demikian, pembelajaran IPA menuntut keterlibatan siswa secara aktif dalam belajar agar siswa mampu menghubungkan antara materi dengan fakta maupun peristiwa yang terjadi di dalam kehidupannya.

Namun berdasarkan pengamatan yang peneliti lakukan di SD Negeri 101801 Kedai Durian, proses pembelajaran IPA masih menggunakan model pempelajaran konvensional dan metode yang di gunakan kurang bervariasi sehingga pembelajaran yang berlangsung cenderung monoton, yaitu guru lebih sering memberikan informasi dan siswa hanya mendengarkan apa yang 
dijelaskan oleh guru dan meringkas pelajaran yang ada pada buku pegangan siswa, sehingga siswa terlihat bosan dan tidak termotivasi untuk belajar IPA serta menyebabkan nilai rata-rata kelas rendah. Pada saat guru menerangkan, siswa tidak ada yang menanggapi dan berani mengajukan pertanyaan kepada guru, jadi interaksi atau komunikasi antara guru dan siswa dalam proses pembelajaran terlihat kurang sehingga pembelajaran IPA Kelas VI SD Negeri No 101801 Kedai Durian. Pada ulangan Semester I Tahun Pelajaran 2015-2016 belum begitu memuaskan. Hal tersebut dapat dilihat dari nilai rata-rata, pada pelajaran IPA. Dimana dari 34 orang siswa, yang mendapat nilai $\leq 70$ sebanyak 23 orang siswa atau sekitar $67,65 \%$, sedangkan yang mendapat nilai $\geq 70$ sebanyak 11 orang siswa atau sekitar 32,35\%.

Kegiatan belajar melalui pembelajaran kontekstual menghadapkan siswa pada pengalaman konkrit sehingga siswa berperan aktif dimana mereka didorong untuk mengambil inisiatif dalam usaha memecahkan masalah, mengambil keputusan dan mengembangkan keterampilan dasar belajar serta melatih siswa untuk menjadi pembelajaran sepanjang hayat.

Atas dasar permasalahan diatas, salah satu alternatif yang dapat dikembangkan untuk memenuhi tuntutan tersebut adalah dengan menerapkan pembelajaran kontekstual di dalam proses pembelajaran, yang diharapkan dapat memberikan kesempatan kepada siswa untuk menghubungkan materi yang di pelajari di sekolah dengan kehidupan sehari-hari. Hal ini menunjukkan bahwa di dalam pembelajaran, siswa menemukan hubungan penuh makna antara ideide abstrak dengan penerapan praktis di dalam konteks dunia nyata. Siswa menginternalisasi konsep melalui penemuan, penguatan, dan keterhubungan. Pembelajaran kontekstual menghendaki kerja dalam sebuah tim baik dalam kelas maupun di laboratorium, pembelajaran kontekstual menuntut guru mendesain lingkungan belajar yang merupakan gabungan beberapa bentuk pengalaman untuk mencapai hasil yang diinginkan.

Materi yang akan digunakan dalam penelitian ini adalah materi pokok bahasan energi dan perubahannya. Pada materi ini, pembelajaran yang akan digunakan dalam penelitian adalah pembelajaran kontekstual, dengan menerapkan pembelajaran kontekstual membantu guru mengaitkan antara materi yang diajarkannya dengan situasi dunia nyata siswa dan mendorong siswa membuat hubungan pengetahuan yang dimiliki dengan penerapannya dalam kehidupan mereka sehari-hari Berdasarkan uraian di atas,
maka penulis tertarik untuk 
mengadakan penelitian dengan judul: "Penerapan Pembelajaran Kontekstual dalam Meningkatkan Hasil Belajar Siswa Pada Mata Pelajaran IPA di Kelas VI SD Negeri No. 101801 Kedai Durian Tahun Ajaran 2015-2016". Adapun tujuan penelitian tindakan kelas ini adalah: untuk meningkatkan hasil belajar siswa dengan menerapkan pembelajaran kontekstual pada mata pelajaran IPA pokok bahasan energi dan perubahannya di Kelas VI SD Negeri No. 101801 Kedai Durian.

\section{METODE PENELITIAN}

Desain penelitian ini adalah tahap-tahap dan tindakan yang dilakukan dalam proses penelitian sesuai dengan tujuan yang ingin dicapai sebagaimana yang dikemukakan Kemmis dan Taggart (Dalam Wiradmadja: 2007: 67), penelitian ini dilaksanakan dalam 2 siklus terdiri atas 4 tahapan utama kegiatan yaitu perencanaan, pelaksanaan, pengamatan, dan refleksi.

Pada tahap pengumpulan data pada penelitian ini, alat yang digunakan adalah tes dan observasi. Analisis data dalam penelitian tindakan kelas ini merupakan suatu usaha untuk memilih, memilah, membuang dan menggolongkan serta menyusun ke dalam kategorisasi, mengklasifikasi data untuk menjawab keberhasilan serta mendukung tujuan penelitian ini. Data yang digunakan dalam penelitian ini yaitu data kuantitatif yaitu tes hasil belajar siswa yang digunakan setelah melaksanakan penelitian.

\section{HASIL DAN PEMBAHASAN}

Pada pertemuan awal sebelum dilakukan siklus I, peneliti terlebih dahulu memberikan pretes kepada siswa (tes awal) pretes bertujuan untuk mengetahui kemampuan awal siswa pada pokok bahasan energi dan perubahannya. Dari hasil pretes yang dilakukan peneliti, diperoleh simpulan bahwa siswa masih tergolong kurang memahami materi energi dan perubahannya sehingga nilai yang diperoleh siswa masih rendah.

Dengan demikian dapat disimpulkan tingkat keberhasilan belajar siswa pada tes awal masih dibawah ketuntasan belajar 70\%, karena siswa belum mampu memahami materi energi dan perubahannya. Untuk mengetahui tingkat persentasi dari ketuntasan klasikal maka peneliti menguraikan pada tabel di bawah ini:

Tabel 1. Deskripsi Hasil Awal Siswa Sebelum Peneliti Menerapkan Pembelajaran Kontekstual

\begin{tabular}{|c|c|c|c|c|}
\hline No & Nilai & $\begin{array}{c}\text { Jumlah } \\
\text { Siswa }\end{array}$ & $\begin{array}{c}\text { Persentase } \\
(\%)\end{array}$ & Keterangan \\
\hline 1 & 30 & 9 & $26,47 \%$ & $\begin{array}{l}\text { Belum } \\
\text { Tuntas }\end{array}$ \\
\hline 2 & 40 & 11 & $32,35 \%$ & $\begin{array}{l}\text { Belum } \\
\text { Tuntas }\end{array}$ \\
\hline 3 & 50 & 6 & $17,64 \%$ & $\begin{array}{l}\text { Belum } \\
\text { Tuntas }\end{array}$ \\
\hline 4 & 60 & 4 & $11,76 \%$ & $\begin{array}{l}\text { Belum } \\
\text { Tuntas }\end{array}$ \\
\hline 5 & 70 & 4 & $11,76 \%$ & Tuntas \\
\hline \multicolumn{2}{|c|}{ Jumlah } & 34 & $100 \%$ & \\
\hline \multicolumn{5}{|c|}{$\begin{array}{c}\text { siswa yang tuntas } 4 \text { orang siswa }(11,76 \%) \\
\text { siswa yang belum tuntas } 30 \text { orang siswa. } \\
(88,23 \%)\end{array}$} \\
\hline
\end{tabular}


Berdasarkan tabel 1 di atas dapat dilihat bahwa rata-rata nilai siswa masih memiliki tingkat keberhasilan dibawah $70 \%$. Sedangkan rata-rata kelas sebesar 45 sehingga baik secara individu maupun secara klasikal hasil belajar siswa masih rendah, sehingga hasil belajar yang diinginkan belum tercapai.

Deskripsi nilai pre-tes siswa dapat digambarkan dalam bentuk diagram batang seperti berikut ini:

\section{Nilai Tes Awal}

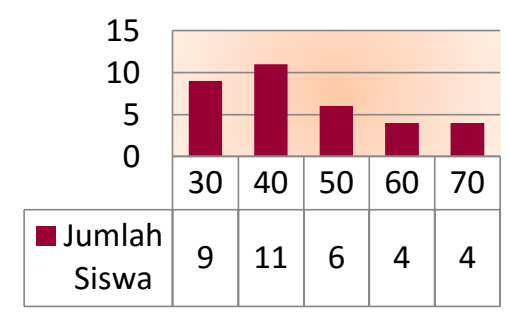

Gambar diagram 1. Nilai Tes Awal

Dari hasil jawaban siswa pada tes awal, menunjukan bahwa siswa masih mengalami kesulitan dalam menyelesaikan soal-soal dari materi energi dan perubahannya, untuk itu perlu di lanjutkan ke siklus I.

\section{Siklus I}

Berikut ini disajikan persentase jawaban siswa dari soalsoal yang diberikan pada Siklus I Analisis data tentang tingkat ketuntasan belajar siswa dapat dilihat pada tabel di bawah ini :
Tabel 2. Deskripsi Hasil Belajar Siswa Setelah Menerapkan Pembelajaran Kontekstual Pada Siklus I

\begin{tabular}{|c|c|c|c|c|}
\hline No & Nilai & $\begin{array}{c}\text { Jumlah } \\
\text { Siswa }\end{array}$ & $\begin{array}{c}\text { Persentase } \\
(\%)\end{array}$ & Keterangan \\
\hline 1 & 40 & 2 & $5,88 \%$ & $\begin{array}{l}\text { Belum } \\
\text { Tuntas }\end{array}$ \\
\hline 2 & 50 & 7 & $20,58 \%$ & $\begin{array}{l}\text { Belum } \\
\text { Tuntas }\end{array}$ \\
\hline 3 & 60 & 9 & $26,47 \%$ & $\begin{array}{l}\text { Belum } \\
\text { Tuntas }\end{array}$ \\
\hline 4 & 70 & 12 & $35,29 \%$ & Tuntas \\
\hline 5 & 80 & 4 & $11,76 \%$ & Tuntas \\
\hline & amlah & 34 & $100 \%$ & \\
\hline \multicolumn{5}{|c|}{$\begin{array}{c}\text { siswa yang tuntas } 16 \text { orang siswa }(47,05 \%) \\
\text { siswa yang belumtuntas. } 18 \text { orang siswa. } \\
(52,94 \%)\end{array}$} \\
\hline
\end{tabular}

Berdasrkan tabel di atas dapat dilihat bahwa persentase nilai siswa masi memiliki tingkat keberhasilan dibawah $70 \%$. Sedangkan rata-rata kelas sebesar 62,64. Sehingga baik secara individu maupun secara klasikal hasil belajar siswa masi rendah, atau tergolong belum tuntas sehingga hasil belajar yang diinginkan belum tercapai. Deskripsi nilai post test siklus I siswa dapat digambarkan dalam bentuk diagram batang seperti berikut ini:

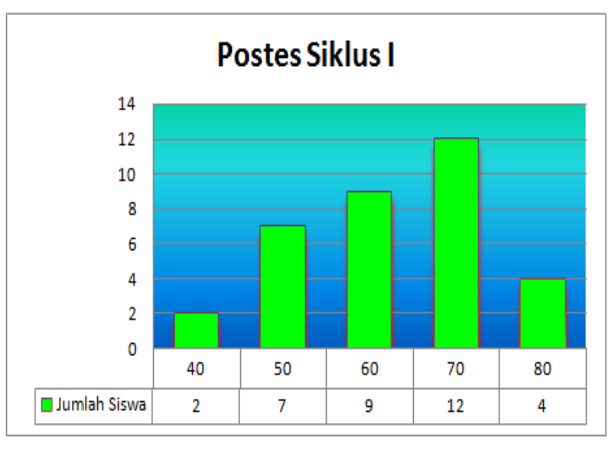

Gambar Diagram 5. Nilai Siklus I Siswa 
Dari hasil jawaban siswa pada tes awal, menunjukan bahwa siswa masih mengalami kesulitan dalam menyelesaikan soal-soal dari materi energi dan perubahannya. Untuk itu perlu di lakukan kembali untuk melanjutkan ke siklus II.

\section{Siklus II}

Setelah

melakukan

pembelajaran dengan menggunakan pembelajaran kontekstual maka peneliti melakukan evaluasi atau post test terhadap peroses pembelajaran yang dilakukan pada akhir siklus II.

Analisis data tentang tingkat ketuntasan belajar siswa dapat dilihat pada tabel berikut ini.

\section{Tabel 3. Deskripsi Hasil Belajar Siswa Setelah Menerapkan Pembelajaran Kontekstual Pada Siklus II}

\begin{tabular}{|c|c|c|c|c|}
\hline No & Nilai & $\begin{array}{l}\text { Jumlah } \\
\text { Siswa }\end{array}$ & $\begin{array}{c}\text { Persentase } \\
(\%)\end{array}$ & Keterangan \\
\hline 1 & 60 & 5 & $14,70 \%$ & $\begin{array}{l}\text { Belum } \\
\text { Tuntas }\end{array}$ \\
\hline 2 & 70 & 7 & $20,58 \%$ & Tuntas \\
\hline 3 & 80 & 9 & $26,47 \%$ & Tuntas \\
\hline 4 & 90 & 10 & $29,41 \%$ & Tuntas \\
\hline 5 & 100 & 3 & $8,82 \%$ & Tuntas \\
\hline & mlah & 34 & $100 \%$ & \\
\hline \multicolumn{5}{|c|}{$\begin{array}{c}\text { siswa yang tuntas } 29 \text { orang siswa }(85,29 \%) \\
\text { siswa yang belum tuntas. } 5 \text { orang siswa. } \\
(14,70 \%)\end{array}$} \\
\hline
\end{tabular}

Dari tabel di atas, diketahui bahwa terdapat 5 orang siswa $(14,70 \%)$ atau yang belum tuntas dalam belajar yaitu memiliki tingkat ketuntasan belajar di bawah $70 \%$ dan yang mencapai ketuntasan belajar sebanyak 29 orang siswa $(85,29 \%)$ dengan rata-rata nilai kelas sebesar 79,70. Dengan demikian dapat disimpulkan bahwa tingkat keberhasilan belajar siswa sudah mencapi nilai standar atau $70 \%$ sehingga hasil belajar siswa suda meningkat.

Dari tabel diatas terlihat bahwa pelaksanaan pembelajaran kontekstual sudah tercapai dan pelaksanaan pembelajaran yang dilakukan peneliti sudah mencapai tindakan yang maksimal terlihat dari perolehan

persentase keberhasilannya yaitu sebesar 79,70.

\section{Post Tes Siklus II}

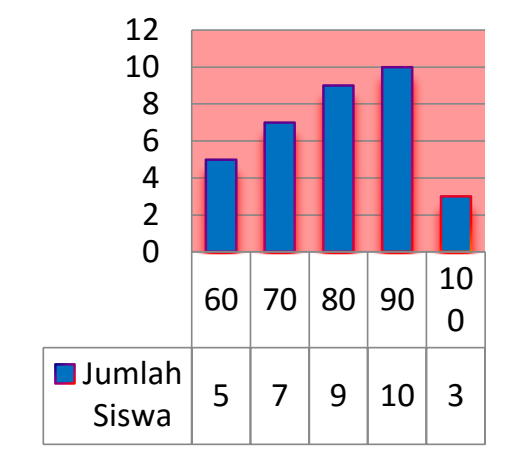

\section{Gambar Diagram 3. Nilai Siklus II Siswa}

Dari hasil pengujian hipotesis yaitu dengan menerapkan pembelajaran kontekstual dapat meningkatkan hasil belajar siswa Kelas VI pada mata pelajaran IPA pokok bahasan energi dan perubahannya. Hasil penelitian, sebelum dilakukannya Siklus I telah 
diberikan tes awal dengan nilai ratarata sebesar 45. Secara perorangan maupun kelas siswa dinyatakan masih belum berhasil dengan kata lain masih memiliki rata-rata tingkat keberhasilan di bawah $70 \%$.

Pada Siklus I digunakan pembelajaran kontekstual dengan menggunakan lingkungan sebagai sumber belajar siswa. Pembelajaran yang diterapkan menggunakan metode demonstrasi, bertanya, dan diskusi kelompok. Pada Siklus I setelah dilakukannya tindakan kemudian diberikan evaluasi ternyata hasilnya meningkat dengan rata-rata nilai 62,64 dan tingkat ketuntasan belajar sebesar 47,05\%. Dalam Siklus I dengan melihat rata-rata nilai dan tingkat ketuntasan belajar masih dinyatakan belum berhasil. Oleh karena itu dilanjutkan pada Siklus II.

Pada Siklus II, ini merupakan perbaikan atau lanjutan pembelajaran yang telah diberikan pada Siklus I. Pada Siklus II ini didapat nilai ratarata sebesar dan tingkat ketuntasan belajar sebesar 85,29\%. Hal ini berarti dengan menerapkan pembelajaran kontekstual dapat meningkatkan hasil belajar siswa pada materi energi dan perubahannya, terlihat dari tingkat ketuntasan belajar siswa dan rata-rata nilai yang diperoleh 79,70.

Berikut ini merupakan penyajian data atau nilai rata-rata siswa dalam diagram batang, tes awal, post tes sisklus I, dan post tes siklus II :

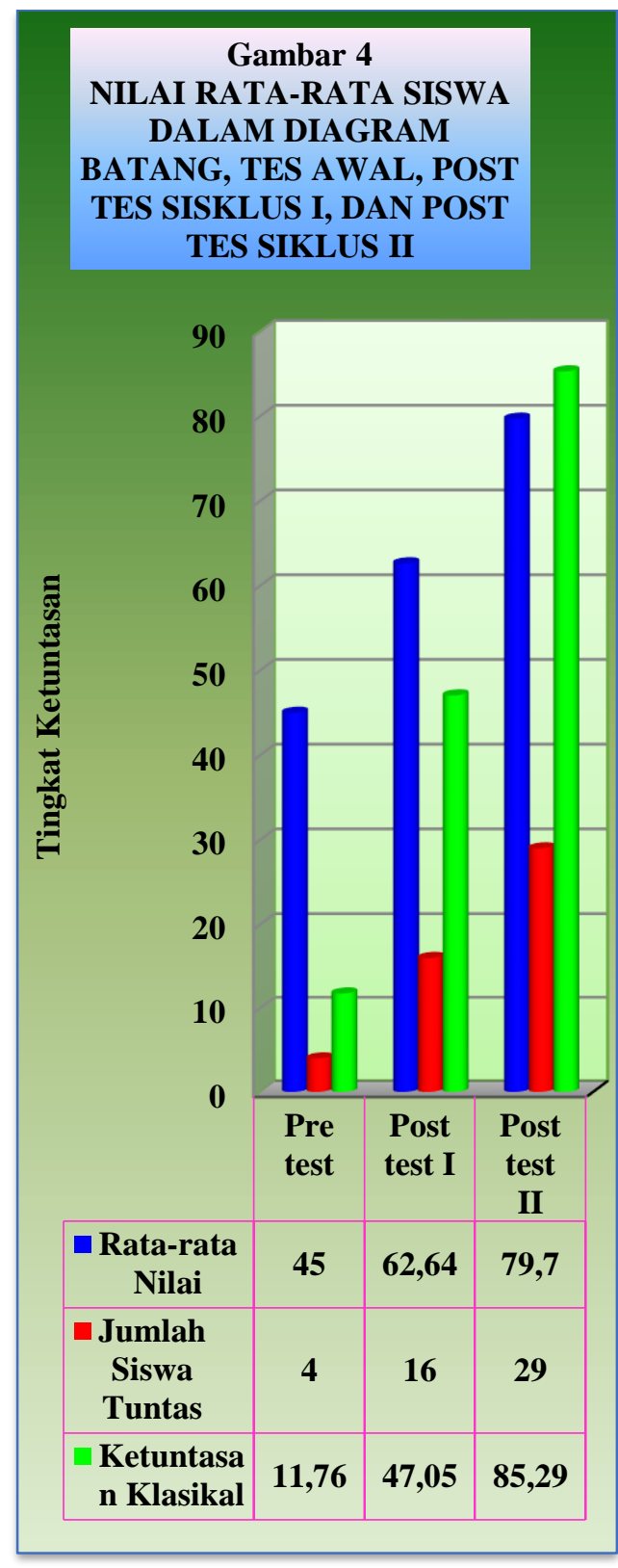

Gambar Diagram 4 : Hasil Belajar Siswa Dilihat Dari Rata-Rata, Nilai Tes Awal,Siklus I, Dan Siklus II

\section{SIMPULAN}

Berdasarkan pembahasan yang telah diuraikan dapat di simpulkan bahwa: 1) Dengan menerapkan pembelajaran 
kontekstual pada mata pelajaran IPA pokok bahasan energi dan perubahannya di Kelas VI SD Negeri No 101801 Kedai Durian dapat meningkatkan hasil belajar siswa.Mulai tes awal hingga pada siklus II yaitu pada tes awal yang dilakukan sebelum siklus I, ada 4 orang siswa $(11,76 \%)$ yang berhasil dalam mencapai ketuntasan belajar dengan rata-rata nilai 45 . Ketuntasan belajar siswa pada post test siklus I mencapai 16 orang siswa yang berhasil dalam mencapai ketuntasan belajar yaitu sebesar $47,05 \%$ dengan rata-rata nilai 62,64 Dan Ketuntasan belajar siswa pada post test siklus II mencapai 29 orang siswa yang berhasil dalam mencapai ketuntasan belajar yaitu sebesar $85,29 \%$ dengan rata-rata nilai 79,70. 2) Pembelajaran Kontekstual merupakan model pembelajaran yang efektif sehingga mendorong siswa untuk mampu menghubungkan antara pengetahuan yang dimilikinya dengan penerapannya dalam kehidupan mereka sehari-hari. Siswa dalam belajar tidak hanya sekedar hafalan atau mengingat fakta saja, karena hal itu akan dilupakan siswa. Seperti pepatah Cina mengatakan, "Saya mendengar maka saya lupa, saya melihat maka saya tahu, saya berbuat maka saya mengerti”.

DAFTAR RUJUKAN

Aqib, Zainal. 2006. Penelitian Tindakan Kelas. Bandung: Yrama Widya.
Daryanto. 2009. Belajar dan Mengajar. Bandung: Yrama Widya.

Djamarah, Bahri. 2002. Strategi Belajar Mengajar. Jakarta: Rineka Cipta.

Kokom, Komalasari. (2010). Pembelajaran Kontekstual Konsep dan Aplikasi. Bandung: Refika Aditama.

Lentiana, Henny. 2009. Evektivitas

Penggunaan Alat Peraga Terhadap Hasil Belajar Siswa Pada Mata Pelajaran IPAKelas VI SD. Medan: Program Pendidikan Guru Sekolah Dasar. Universitas Negeri Medan.

Muslic, Mansur. 2009. KTSP Pembelajaran Berbasis Kompetensi dan kontekstual. Jakarta. Penerbit. Bumi Aksara.

Puskur Balitbang Depdiknas. 2007. Naskah Akademik Kebijakan Kurikulum Mata Pelajaran Ilmu Sosial. Puskur Balitbang Depdiknas. Jakarta.

Purwanto. 2009. Evaluasi Hasil Belajar. Surakarta : Pustaka Belajar.

Rahmadayanti, Fitri. 2009. Meningkatkan Hasil Belajar Matematika Dengan 
Pendekatan Kontekstual pada sub pokok bahasan perkalian. Medan: Program Pendidikan Guru Sekolah Dasar. Universitas Negeri Medan: Skripsi tidak dipublikasikan.

Sadali. 2000. Pengaruh Penerapan Model Pembelajaran Role Playing Terhadap Aktivitas Guru dan Hasil Belajar dalam Mata Pelajaran Pendidikan IPA di Sekolah Dasar. Brebes: Lembaga Penelitian Universitas Terbuka. Skrispsi tidak dipublikasikan.

Riyanto, Yamin. 2010. Peradigma Baru Pembelajaran. Jakarta: Kencana.

Selameto. 2003. Belajar dan Faktorfaktor yang Mempengaruhinya. Jakarta: Reneka Cipta.

Sudjana, Nana. 2008. Penilaian Hasil Proses Belajar Mengajar. Bandung: Remaja Rosdakarya.

Sumantri, Suryana. 2001. Perilaku Organisasi. Bandung: Universitas Padjadjaran.

Uno, Hamzah. 2012. Belajar dengan Pembelajaran Paikem. Jakarta: Bumi Aksara. 